\title{
MORPHOLOGICAL DEVIATIONS PRODUCED BY INDONESIAN ADOLESCENT DYSLEXIC READERS
}

\author{
Angkita Wasito Kirana ${ }^{1}$ Masitha Achmad Syukri ${ }^{2}$ Deny Arnos Kwary ${ }^{3}$ \\ Fakultas Vokasi, Universitas Airlangga ${ }^{1}$ Fakultas Ilmu Budaya, Universitas Airlangga ${ }^{23}$ \\ angqtha@gmail.com ${ }^{1}$
}

\begin{abstract}
Even though the major problem of dyslexic readers is in their phonological awareness, the morphological complexity of a language might also affect their performance in reading, especially for a language with transparent orthography like the Indonesian language. This study aims to find the patterns of morphological deviations produced by Indonesian dyslexic adolescents during a reading activity. In this study, a number of 160 words that were chosen based on their morphological complexity were included in a set of reading instrument. The words were included into 55 sentences which then were asked to be read aloud by the participants. The result indicated that the morphological deviations which occurred during the test were equally frequent, both in words that have inflectional and derivational affixes. Most of the morphological deviation (96\%) occurred in polymorphemic words. In addition, the participants tend to simplify the polymorphemic words by omitting the affixes and reading only the root word. At least $58 \%$ of the deviations were affix omission. This means teachers of dyslexic readers need to provide more training on polymorphemic words, particularly those that have affixes.
\end{abstract}

Keywords: dyslexia, adolescent, morphological deviation, affixes, reading aloud

\begin{abstract}
Abstrak
Meskipun masalah utama pembaca dengan disleksia ada pada kesadaran fonologis mereka, kerumitan morfologis suatu bahasa juga berpengaruh pada kemampuan mereka dalam membaca, khususnya pada bahasa dengan ortografi yang transparan seperti bahasa Indonesia. Penelitian ini bertujuan untuk mengetahui pola penyimpangan morfologis yang dihasilkan remaja penderita disleksia pada saat mereka membaca. Dalam penelitian ini, sejumlah 160 kata yang dipilih berdasarkan kompleksitas morfologisnya dimasukkan dalam satu perangkat alat bacaan. Kata-kata tersebut kemudian dimasukkan ke dalam 55 kalimat yang dibacakan dengan keras oleh para partisipan. Hasil penyimpangan morfologis menunjukkan bahwa penyimpangan yang terjadi selama tes adalah sama seringnya, baik pada kata berimbuhan infleksional maupun derivasional. Sebagian besar penyimpangan morfologis $(96 \%)$ terjadi pada kata-kata polimorfemik. Selain itu, peserta cenderung menyederhanakan kata-kata polimorfemik dengan menghilangkan imbuhan dan hanya membaca kata dasarnya. Setidaknya $58 \%$ dari penyimpangan tersebut merupakan penghapusan imbuhan. Ini berarti para guru yang mengajar pembaca dengan disleksia perlu memberikan lebih banyak pelatihan membaca khususnya pada kata-kata polimorfemik, terutama yang memiliki imbuhan.
\end{abstract}

Kata kunci: disleksia, remaja, penyimpangan morfologis, imbuhan, membaca dengan keras 


\section{INTRODUCTION}

Dyslexia is often associated with the deficiencies in phonological awareness (Anjarningsih, 2011; Patel et.al, 2011; Bellocchi, et al, 2013; Lallier, et al, 2014; Valdois, et al, 2014). However, problems with phonological manipulation skills are less apparent in the languages of shallow orthography (Kałdonek-Crnjaković, 2015). Moreover, reading is also a complex ability which involves a lot of different constituent processes that operate in parallel (McNamara, \& Kendeou, 2011; De Groot, 2013). Among those constituents required in reading, morphological awareness is considered to be one of the factors that affect dyslexic readers reading ability (Chung, et al, 2010; Chik and Ho, 2012).

A number of previous studies have found that morphological awareness is one of the contributing factors in decoding stage (Tong, et al., 2011; Kieffer, 2014). Morphological awareness can be related to word recognition (Law, et al, 2017) which is one of the tasks required to be accomplished during reading (Sprenger-Charoles \& Cole, 2003 in Berthiaume \& Daigle, 2014, p. 253). The deficiency in morphological awareness correlates with reading difficulties in language with alphabetic orthography (Casalis, Colé \& Sopo, 2004; Burani, et al., 2008) as well as morphographic or morphosyllabic orthography such as Japanese language Hiragana and Kanji (Muroya, et al., 2017).

The problems might arise when the readers were at school. Most activities in their academic life involve reading and writing. Their failure to identify certain written words makes them read incorrectly. Thus, these children can hardly catch up their same-age friends in understanding the lesson since they often have difficulty to understand the written language. Therefore, even though dyslexic readers are highly intelligent (Beaton, 2004), this impairment may affect their academic performance. In addition, if the impairment is not immediately treated, later in their lives it may affect their achievements.

Nevertheless, in treating the students with dyslexia, it is important to understand the process of reading to find out which reading ability is impaired. Thus, the treatment can be more effective and efficient. In addition, there are processes that occur in reading, but sometimes not every dyslexic student suffers from all of them. Reading requires a set of complex cognitive abilities as it involves progressive and interactive integration of various cognitive processes (Koda, 2005).

Even though word recognitions commonly focus on phonological processes which become the suspect of the cause of the reading failure in dyslexic readers (Bosse \& Valdois, 2003), recent studies indicated that morphological processes also cause the readers to struggle (Casalis, Colé \& Sopo, 2004; Burani, et al., 2008; Siegel, 2008). Burani (2009) also found that even in languages with transparent orthography such as Italian, dyslexic children tend to be accurate when they read aloud non-words which have morphemes compared to the root non-words. In addition, she assumed that morphology-based reading strategy in dyslexics is semantic, as it may involve meaning extraction from the morphemic units (stems and affixes) constituting the word. As Zhang, et al. (2014) claimed, during reading, word recognition through chunking reduces the load of working memory needed to read morphologically complex words. Those kinds of words, which are usually affixed words or compound words, tend to be long. Moreover, studies showed that the ability to read a root word is also associated with the accuracy in reading a derived form of that word (Goodwin, Gilbert \& Cho, 2013).

Similar to the Italian language in Burani's studies, Indonesian language, which is also quite transparent in orthography, involves different kinds of affixes in its words. Each affix might 
change the meaning of the root word, and therefore the morphological aspects in reading is also associated with the meaning retrieval process during reading activity (Carlisle \& Fleming, 2003; Pacheco \& Goodwin, 2013). As an attempt to find the contributing deviations in the reading comprehension of dyslexic students, this study investigated morphological deviations produced by two dyslexic adolescents during reading activity and tried to find out the patterns of those produced morphological deviations.

\section{THEORETICAL FRAMEWORK}

\section{Reading Process}

The reading processes are divided into two levels, the lower and higher level (Field, 2003). In the process of reading, the lower level includes the coding phase and stage of accessing lexical storage. This stage requires phonological abilities, alphabetic knowledge, and rapid naming abilities, along with basic cognitive knowledge (Papodopoulos, et al., 2014). In the coding stage, readers recognize words in the text and they access their lexical storage in their brains. In this process, the readers access the units that represent both the written form and speech form of the word as a whole as well as its components. In a person who has a high ability in reading, the process is almost automatic and effective (Field, 2003; De Groot, 2013). On the basic level, learning to read requires children to form a set of mappings between the letters of the printed word (grapheme) and the speech sounds (phonemes) (Snowling and Stockhouse, 2006). Graphemes and phonemes can be used as a segmentation to recognize a word where each grapheme is assigned to a phoneme or sound (Sprenger-Charolles, Siegel, \& Bonnet, 1998). In this process, the sequence of the letters of a word is processed to access its meaning in the mental lexicon (Ziegler \& Goswami, 2005; Sprenger-Charolles, et al., 2011).

\section{Morphological processes}

Kridalaksana (1989) stated that in language, morphological occurrence started from input, which is lexeme, and one of the morphological processes, and ended with the production of the output, which is words. This process shows that word is differed from lexeme. Kridalaksana defined a lexeme as the following:

1. the smallest unit in lexicon

2. the input in morphological processes

3. the raw material in morphological processes

4. a substance which existence is known to be the base form that is free from morphological processes after being segmented from its complex form

5. a form that is not categorized as prolexeme or particles.

Therefore, words are not the basic unit, instead they act as the product or the output of a morphological unit. Kridalaksana also stated that after undergoing morphological processes, a lexeme will get its new form as well as new meaning (except in the process of zero derivation). In other words, since the process might develop new meaning of the base form, it can have some contributions in the reading performance of children with dyslexia, both in the accuracy and comprehension. Thus, in analysing the data, the present study will consider this process. However, since the language used in the current study is Indonesian language, the theory of morphological 
processes in Indonesian language which is proposed by Kridalaksana (1989) is chosen as the one of theoretical framework. In his book, Kridalaksana stated that the morphological processes found in Indonesian language are:

a. Zero derivation

In this process a lexeme becomes a single word without any change.

b. Affixation

A process which changes a lexeme into a complex word after undergoing a process in which affix/es are attached to them. In this process the form of the lexeme changes into particular category. In addition, the meaning of the lexeme also changes. However, in the formation of a complex word in Indonesian language, the affixes develop a system. Therefore, the occurrence of a word in Indonesian is a combination of processes that are linked to each other. Table 1 shows the types of affixes in Indonesian.

Table 1. Affixes in Indonesian (Kridalaksana, 1989)

\begin{tabular}{|c|c|c|c|}
\hline No & Affix & Description & Example \\
\hline 1 & Prefix & $\begin{array}{l}\text { Affixes that are placed in front of } \\
\text { the root }\end{array}$ & $\begin{array}{l}\text { me-, di-, ber- ke-, ter-, } \\
\text { pe-, per-, se- }\end{array}$ \\
\hline 2 & Infix & $\begin{array}{l}\text { Affixes that are placed within the } \\
\text { root }\end{array}$ & -el-, -er-, -em-, -in- \\
\hline 3 & Suffix & $\begin{array}{l}\text { Affixes that are placed behind the } \\
\text { root }\end{array}$ & $-a n,-k a n,-i$ \\
\hline 4 & Simulfix & $\begin{array}{l}\text { Affixes that are manifested with } \\
\text { segmental characteristics which are } \\
\text { merged in the root }\end{array}$ & $\begin{array}{l}\text { Nasalitation of the first } \\
\text { phoneme of the root; } \\
\text { ngopi, nyoto }\end{array}$ \\
\hline 5 & Confix & $\begin{array}{l}\text { Affixes that consist of two } \\
\text { substances; one in the front of the } \\
\text { root and the other behind the root }\end{array}$ & $\begin{array}{l}\text { ke-an, pe-an, per-an, ber- } \\
\text { an }\end{array}$ \\
\hline 6 & $\begin{array}{l}\text { Combination } \\
\text { of affix }\end{array}$ & $\begin{array}{l}\text { The combination of two or more } \\
\text { affixes which is combined with the } \\
\text { root }\end{array}$ & $\begin{array}{l}\text { memper-kan, memper-i, } \\
\text { member-kan, me-kan, } \\
\text { me-i, ber-kan, ter-kan, } \\
\text { per-kan, pe-an, se-nya }\end{array}$ \\
\hline
\end{tabular}

As stated previously, affixation is a system of process. This means that if a lexeme undergoes this process, there is/are sequence/s of occurrence that contribute not only to the change of form of that particular lexeme, but also the class. The system of affixation process is described in Table 2 . 
Table 2. Derivational Affixes in Indonesian (Kridalaksana, 1989)

\begin{tabular}{|c|c|c|c|}
\hline No & Types of Affix & Example & \\
\hline \multirow[t]{5}{*}{1} & $\begin{array}{l}\text { Affixes that form } \\
\text { the verbs }\end{array}$ & Prefix & me-, ber-, per-, ter-, ke-, se- \\
\hline & & Suffix & $-i n$ \\
\hline & & Confix & ber-an, ber-kan, ke-an \\
\hline & & Simulfix & $N-$ \\
\hline & & $\begin{array}{l}\text { Combination of } \\
\text { affixes }\end{array}$ & $\begin{array}{l}\text { me-i, di-i, me-kan, memper-, diper-, memper-kan, } \\
\text { diper-kan, } N-i \text {, ter-kan, per-kan, per-i, ber-kan }\end{array}$ \\
\hline \multirow{5}{*}{2} & $\begin{array}{l}\text { Affixes that form } \\
\text { the adjectives }\end{array}$ & Prefix & se-, ter-, ber-, me-, pe- \\
\hline & & Infix & -em-, -in- \\
\hline & & Suffix & -an, -al, -il, -iah, -if, -ik, -is, -istis, $-i$ \\
\hline & & Confix & ke-an \\
\hline & & $\begin{array}{l}\text { Combination of } \\
\text { affixes }\end{array}$ & $m e-i$, me-kan \\
\hline \multirow{5}{*}{3} & $\begin{array}{l}\text { Affixes that form } \\
\text { the noun }\end{array}$ & Prefix & ke-, pe-pe-, per-, se \\
\hline & & Infix & -el-, -er- \\
\hline & & Suffix & $\begin{array}{l}\text {-an, -at, -si, -ika, -in, -ir, -ur, -ris, -us, -isme, -is, - } \\
\text { isasi, -isida, -ita, -or, -tas }\end{array}$ \\
\hline & & Confix & ke-an, pe-an, per-an \\
\hline & & $\begin{array}{l}\text { Combination of } \\
\text { affixes }\end{array}$ & $\begin{array}{l}\text { keber-an, kese-an, keter-an, pember-an, pemer- } \\
\text { an, penye-an, perse-an }\end{array}$ \\
\hline \multirow[t]{2}{*}{4} & $\begin{array}{l}\text { Affixes that form } \\
\text { the adverb }\end{array}$ & Prefix & $\mathrm{se}-$ \\
\hline & & Confix & se-nya, se-R-nya \\
\hline \multirow{3}{*}{5} & $\begin{array}{l}\text { Affixes that form } \\
\text { the number }\end{array}$ & Prefix & ke-, ber- \\
\hline & & Suffix & $-a n$ \\
\hline & & Confix & ber-an \\
\hline \multirow{3}{*}{5} & $\begin{array}{l}\text { Affixes that form } \\
\text { the interrogative }\end{array}$ & Prefix & $m e-$ \\
\hline & & Suffix & $-a n$ \\
\hline & & $\begin{array}{l}\text { Combination of } \\
\text { affixes }\end{array}$ & me-kan, $N$-in \\
\hline
\end{tabular}


c. Reduplication

In this process a lexeme becomes a complex word after undergoing several kinds of repeated processes. Kridalaksana explained that there are three types of reduplication, namely:

1. Phonological reduplication which occurrence does not cause the change in meaning as the repetition is only phonological by nature. In other words, there is no lexeme repetition. The examples of this process can be seen in words such as dada, pipi, kuku, paru-paru.

2. Morphemic reduplication which occurrence causes the change in grammatical meaning due to the repetition of the lexeme.

3. Syntactical reduplication which occurs due to the repetition of a lexeme, and produces a unit which is a clause. The example of this can be seen in the following sentence: Jauhjauh, didatangi juga rumah temannya itu.

d. Abbreviation

In this process a lexeme or joint lexeme becomes a complex word or acronym or abbreviation with various abbreviation processes. There are several types of abbreviation, namely fragmentation, contraction, acronym, initialism, and the letter-word. In fragmentation and contraction, the input is a single lexeme and the output is a complex word as in affixation and reduplication. Meanwhile, in the acronym and initialism, the input is two or more lexemes and the output is acronym or abbreviation, and the grammatical status is word. The letter-word is a process of abbreviation which produces one or more letter which describes the basic concept of the quantity, unit, or substance such as $\mathrm{g}$ for gram or $\mathrm{H}$ for hydrogen.

e. Compounding

In this process two or more lexemes combine together and the output is the combination of the lexemes. One example of this morphological process is buta warna 'colour blind'. This composition, composite, is different from a phrase. Kridalaksana claimed that this lexeme composition is the product of morphological processes. Meanwhile, the phrase is the product of syntactical processes. He described that there is nothing that can be inserted in the composite. As an example of this, he showed the difference between buta warna 'colour blind' with alat negara 'instrument of the nation'. Nothing can be inserted in buta warna, but the particle dari 'of' can be inserted in alat negara. Another characteristic of a composite is that each of its lexeme cannot be added with an affix. The affix should cover the whole lexemes. He illustrated this in kereta api 'train'. If an affix is added to the two words, then the form should be perkeretaapian. The lexemes are not separated. The last characteristic is that the sequence of lexeme cannot be rearranged. This composite is also different from coordinative phrases such as pulang pergi and lebih kurang. The construction of a composite such as arif bijaksana and hutan belantara cannot be rearranged.

f. Back formation

In this process the input is a single lexeme and the output is a complex word. The process is similar to affixation. 
Kridalaksana (1989) also stated that the formation of words through morphological processes is a cyclical process, therefore a formed word might undergo a similar process and develop to be another word. However, this cycle has its limitation, and that is conventional acceptance. In other words, as long as the formed word is acceptable by the convention, the formed word can be used. Kridalaksana explained that some limitation involves the number of morphological process that is allowed to occur in the cycle. He illustrated the example of this in the affixation process of the prefixes me- and $d i$-. Convention cannot accept the use of prefix $d i-$ and $m e$ - to be used simultaneously with the exception of the word dimengerti. However, the use of the prefix me-and ber-sequentially is acceptable.

\section{METHODS}

The participants in the current study were two dyslexic inclusive junior high school students, in grade 7 and 9 , aged 14 and 16 years old, respectively. The range of grades was chosen considering that at that grade the students are exposed to sufficient amounts of readings. Moreover, the students have been taught to read for quite a long time. Therefore, it was expected that they would be able to read at least some basic words and simple sentences. The participants were asked to read 160 words that were constructed into 55 sentences. Those words were chosen from the words that appear in the reading texts in five student books of Indonesian Language lesson for Grade 6. The student book for grade 6 was chosen because there is an unknown degree of delay in the reading ability experienced by the dyslexic students despite of the sufficient amount of language exposure. Therefore, the vocabularies used in grade six were chosen with the assumption that their range of frequency and difficulties were equal with the reading ability that was expected to be acquired by the participants.

The morphological aspects taken into account were the length of the monomorphemic word (monosyllabic and polysyllabic words) and the length of polymorphemic words (inflectional affixation and derivational affixation). The reading test was done in several different days for each student to avoid the boredom experienced by the students. The process was recorded using a voice recorder. After the transcription process, the morphological deviations were identified. It was then followed by the categorization of morphological deviation, namely affix addition, omission, combination, affix substitution, root substitution, suppletion, syllable addition. Deviations made by both participants were counted as separate data even though the deviation might occur in the same target word or share a similar form.

\section{RESULTS AND DISCUSSION}

\section{The Frequency of Morphological Deviations}

The morphological deviations occurred in both inflectional and derivational affixations in polymorphemic words. There were only two deviations that occurred in monomorphemic words. Table 3 listed the frequency of each type of morphological deviations. 
Table 3. The Frequency of Morphological Deviations

Polymorphemic words

\begin{tabular}{|c|c|c|c|c|}
\hline No & Type of process & Type of affix & Frequency & Total frequency \\
\hline 1 & Affix Addition & derivational & & 1 \\
\hline \multirow{2}{*}{\multicolumn{2}{|c|}{2 Omission }} & inflectional & 6 & \multirow{2}{*}{8} \\
\hline & & derivational & 2 & \\
\hline 3 & Affix Substitution & derivational & & 1 \\
\hline \multirow{2}{*}{4} & \multirow{2}{*}{ Root substitution } & inflectional & 2 & \multirow{2}{*}{3} \\
\hline & & derivational & 1 & \\
\hline \multirow{2}{*}{5} & \multirow{2}{*}{ Combination } & inflectional & 2 & \multirow{2}{*}{8} \\
\hline & & derivational & 6 & \\
\hline 6 & Syllable addition & & & 1 \\
\hline \multicolumn{5}{|c|}{ Monomorphemic words } \\
\hline \multirow[t]{2}{*}{1} & Suppletion & monomorphemic & 2 & \\
\hline & Total & & & 24 \\
\hline
\end{tabular}

During the reading test, 24 deviations were found. The morphological deviations occurred mostly in words with affixes. This study prepared 80 roots, yet only two of them were misread. On the contrary, among the 80 words with affixes prepared, 22 of them were misread. Law, et al. (2017) argued that a hierarchical structure of linguistic units is employed during early visual word processing in which the processing of smaller linguistic units is required to process larger-size units. He argued that such situation would ultimately limit the visual processing of morphemes, thus limiting the morphological process. In other words, the more morphologically complex the words are, the more limited the morphological process of dyslexic readers is. That is why, there were more deviations found in polymorphemic words compared to monomorphemic words. Similarly, Deacon, Parilla, and Kirby (2006) found that there was a lack of sensitivity to the derivational structure of written words in high functioning dyslexic. This might be the reason why the participants in this study produced deviations in words with derivational affixes.

\section{The Types of Morphological Processes that Occurred in the Deviations}

In this study, among the 24 morphological deviations that were found, $91.7 \%$ of them occurred in polymorphemic words. This revealed that adolescent dyslexic readers may have difficulties in segmenting the polymorphemic words morphoplogically. If Casalis, Colé, and Sopo (2004) found that children with dyslexia were found to be poorer in morphological segmentation tasks when compared with reading-age controls, the adolescent dyslexic readers in this study were expected to have no or just relatively less deficit on decoding process. They are assumed to have longer language exposures, experiences, and reading practices. However, they still have those deficits in processing the longer words.

Table 4 below lists both the target words and the deviations that occurred during the reading test. It also showed how each participant produced their deviations. 
Table 4. The Types of Morphological Deviation

\begin{tabular}{|c|c|c|c|c|c|}
\hline No $\begin{array}{l}\text { Types of } \\
\text { affixes }\end{array}$ & $\begin{array}{l}\text { Types of } \\
\text { processes }\end{array}$ & Target Word & Produced word & & Participant \\
\hline & & & Meaningful & $\begin{array}{l}\text { Meaning- } \\
\text { less }\end{array}$ & \\
\hline $\begin{array}{l}\text { Polymorphemic } \\
\text { words }\end{array}$ & \multicolumn{5}{|c|}{ Inflectional } \\
\hline 1 Inflectional & Affix omission & memenangkan & menang & & $\mathrm{P} 1$ \\
\hline 2 Inflectional & Affix omission & $(1003)$ & menang & & $\mathrm{P} 2$ \\
\hline 3 Inflectional & Affix omission & rakyatnya (2802) & rakyat & & $\mathrm{P} 2$ \\
\hline 4 Inflectional & Affix omission & $\begin{array}{l}\text { kameranya } \\
\text { (4701) }\end{array}$ & kamera & & $\mathrm{P} 2$ \\
\hline 5 Inflectional & Affix omission & tugasnya (2901) & tugas & & $\mathrm{P} 2$ \\
\hline 6 Inflectional & Affix omission & $\begin{array}{l}\text { membuatnya } \\
\text { (1101) }\end{array}$ & buatnya & & $\mathrm{P} 2$ \\
\hline 7 Inflectional & $\begin{array}{l}\text { Omission- affix } \\
\text { substitution }\end{array}$ & $\begin{array}{l}\text { menghadiahinya } \\
\text { (901) }\end{array}$ & menghadiahkan & & P1 \\
\hline 8 Inflectional & $\begin{array}{l}\text { Omission- affix } \\
\text { substitution }\end{array}$ & & menghadiahkan & & $\mathrm{P} 2$ \\
\hline 9 Inflectional & Root substitution & $\begin{array}{l}\text { mengagumi } \\
(3601)\end{array}$ & mengampuni & & $\mathrm{P} 2$ \\
\hline 10 Inflectional & Root substitution & diterkam (1601) & ditangkap & & $\mathrm{P} 2$ \\
\hline 11 Inflectional & Syllable insertion & keluargaku (702) & keluarga aku & & $\mathrm{P} 2$ \\
\hline $\begin{array}{l}\text { Polymorphemic } \\
\text { words }\end{array}$ & \multicolumn{5}{|c|}{ Derivational } \\
\hline 1 Derivational & Affix omission & $\begin{array}{l}\text { rerumputan } \\
\text { (2002) }\end{array}$ & & rumputan & $\mathrm{P} 2$ \\
\hline 2 Derivational & Affix omission & sesekali (1601) & sekali & & $\mathrm{P} 2$ \\
\hline 3 Derivational & Affix addition & terkenal (1103) & & keterkenal & $\mathrm{P} 2$ \\
\hline 4 Derivational & $\begin{array}{l}\text { Affix } \\
\text { substitution }\end{array}$ & perangnya(3703) & berperang & & $\mathrm{P} 2$ \\
\hline 5 Derivational & $\begin{array}{l}\text { Affix omission, } \\
\text { root \& affix } \\
\text { substitution }\end{array}$ & kerajaan (2203) & kerjanya & & $\mathrm{P} 1$ \\
\hline 6 Derivational & $\begin{array}{l}\text { Affix } \\
\text { substitution \& } \\
\text { root substitution }\end{array}$ & penebang (3502) & menembak & & $\mathrm{P} 2$ \\
\hline 7 Derivational & $\begin{array}{l}\text { Affix addition \& } \\
\text { affix substitution }\end{array}$ & berjalan (402) & perjalanan & & $\mathrm{P} 2$ \\
\hline 8 Derivational & $\begin{array}{l}\text { Affix omission \& } \\
\text { root substitution }\end{array}$ & & sebagai & & P1 \\
\hline 9 Derivational & $\begin{array}{l}\text { Affix omission \& } \\
\text { root substitution }\end{array}$ & sebagian (2903) & sebagai & & $\mathrm{P} 2$ \\
\hline 10 Derivational & $\begin{array}{l}\text { Affix omission \& } \\
\text { root substitution }\end{array}$ & $\begin{array}{l}\text { sekawanan } \\
\text { (2003) }\end{array}$ & sekelas & & $\mathrm{P} 2$ \\
\hline 11 Derivational & Root substitution & berawan (1201) & berwarna & & $\mathrm{P} 2$ \\
\hline
\end{tabular}




\begin{tabular}{lllll}
\hline $\begin{array}{c}\text { Monomorphemic } \\
\text { words }\end{array}$ & & & \\
\hline 1 Root & Suppletion & pahlawan $(3801)$ & perawan & P2 \\
\hline 2 Root & Suppletion & zebra $(N)(2003)$ & sebelah & P2 \\
\hline
\end{tabular}

Among the deviations occurred in words with affixes, the deviations in inflectional and derivational affixes appeared equally $(\mathrm{N}=11$ each, $45,8 \%)$. This implied that adolescent dyslexic readers may have difficulties in complex words which have affixes in it. Previous studies suggested that morphological awareness is related to word recognition (Kieffer, 2014; Cavalli, et al., 2017; Law, et al., 2017). Therefore, lacking morphological awareness might cause delayed ability in recognising words which reflected in their struggle, errors, or difficulties in reading. In accordance with Undheim (2009), the occurrence frequency of this deviation and the age of the participant implied that despite the length of language exposure, experience, and reading practices, the deficits in the decoding stage remained present in dyslexic readers even in adolescents. The results of this study showed that the deviations appeared equally in words with either derivational or inflectional affixes.

Carlisle (2000) argued that morphological awareness, as it contributes to reading, has the ability to parse words and analyse constituent morphemes for the purpose of constructing meaning. This implied that there were two indicators that determined the ability related to morphological awareness, and they are (1) parsing the words based on the constituent morpheme, and (2) use the constituent morphemes to construct the word meaning. The data showed that while the participants seemed to be able to apply the first indicator, parsing the words, they were unlikely aware of how each constituent morpheme contributed to the construction of the word meaning. This can be seen from the deviations in words with inflectional and derivative affixes. Moreover, it apparently contributed to the number of the deviations they produced especially in words with inflectional affixes.

In addition, Freyd and Baron (1982) found in their research that children and adolescents who were involved in their study tended to base their definitions on the base words, often ignoring or misrepresenting the meaning of the suffixes. In line with their study as well as Carlisle's (2000), in inflectional affixes, half of the deviations in this study were produced due to the suffix omission made by the participant. Three of which occurred in words with possessive suffixes -nya (in English, -nya represents his, hers, my, your, or its). The omission of the possessive suffix indicated that, while preserving and making their understanding based on the root, the participants neglected the possession meaning. This was implied in the word that was expressed by the suffix (see target words 2802, 4701, and 2901 in Table 2). Similar tendency can also be seen when the participants preserved the root and substituted the affixes with another affix which could change the word meaning as shown in deviations in derivative words (see Table 2). Another example is shown in the word memenangkan 'make something/someone to win'. The participants omitted all of the affixes (me- and -kan) and only read the root menang 'to win', which slightly changed the sense of the word.

Regarding the morphological deviations that were meaningful (92\%), the data indicated that they did not have lack of sensitivity on the morphological structure (both inflectional and derivational) during the visual word recognition. They were likely to utilize morpho-orthographic and morpho-semantic information differently. Such condition also happened when they read the monomorphemic words. The words produced twice are deviated morphologically (in the form of 
suppletion type), yet they were still meaningful. The meaningfulness is likely mostly considered in recognizing the words visually by the participants.

The data also showed that morphological deviations mostly occurred in the polymorphemic words. In addition, the most frequent type of the process was omission (58\%). Among all of the affix omissions, the most frequent omission occurred in suffix (64\%). Only two omissions occurred in the prefix. Similarly, there were two occurrences of prefix + suffix omission. Only one affix omission occurred in infix. This indicates that, during the reading activity, the participants tend to preserve the prefix. As Paap et al. (1982) suggest in their activationverification model, during reading, particularly in word recognition stage, there is a process where the first letter units and then word units are activated in a serial, but cascaded, fashion. This means that the information passes through the system before initial processing is complete. In this model, the word is recognized based on the position of the letters in the words and is conceptualized as a feature matching process. In this model, there is a probability when the readers activate an incorrect but similar in letter feature at each letter position and is being processed further during the activity in the lexicon level. Paap et al. (1982) also argued that in the situation of normal reading, in the lexicon level, there is a 'searching' activity to find word candidates in the mental lexicon that suits the perceptual representation of the word that is being read. The word candidates are then being verified to find the most suitable word. However, if there is a sufficient match between a word candidate with the perceptual representation at any point, the candidate is accepted and the verification process is terminated.

Based on the activation-verification model (Paap et al., 1982), the data indicated that the word recognition process was only partially completed by the participants. The process stopped when the participants thought they had found the sufficiently matching word in their mental lexicon based on their perceptual representation that came from the initial letters of the words they read. Therefore, during the reading activity, the omissions that the participants made mostly occurred in the suffixes of the polymorphemic words. The examples below showed some of the sentences as how it should be read accurately (labelled as Target) and how the participants read them (labelled as the number of the participant).

1601 (Target) anak itu sangat lincah sehingga kakaknya sesekali berlari mengejarnya. 'That kid (is) very agile so that his older sibling (once in a while) runs to chase him' anak itu sangat lincah sehingga kakaknya sekali berlari mengejarnya. (Participant 2) 'That kid (is) very agile so that his older sibling (once) runs to chase him'

1001 (Target) Suara Nanda sangat merdu, makanya dia selalu memenangkan lomba menyanyi. 'Nanda's voice is so melodious, therefore she always (make herself win) singing competition'

Suara Nanda sangat merdu, makanya dia selalu menang lomba menyanyi. (Participant 1) 'Nanda's voice is so melodious, therefore she always (wins) singing competition'

2801 (Target) Raja memerintahkan rakvatnva untuk tinggal di rumah saat badai datang. 'The King orders (his people) to stay at home when the storm comes'

Raja memerintahkan rakyat untuk tinggal di rumah saat badai datang. (Participant 2) 'The King orders (people) to stay at home when the storm comes' 
In addition, to obtain more effectivity and shorter time, the participants preferred to omit the affixes. Just as Cavalli, et al. (2017) found in his reading task related to words with affix (suffixation words decision and suffixed word detection) delivered to dyslexic adults, his participants showed poorer efficiency and longer response time than the control-age group. Therefore, to achieve more effectivity and shorter time, omitting the affix was the favored strategy.

This illustration demonstrated the strategy taken by the participants in reading those words: omitting the affix(es) or reading only the root words. Just as Cavalli, et al. (2017) found, to achieve more effectivity and shorter time, omitting the affix and reading the root are the more preferred strategies that were chosen by the participants.Hence, they chose the shorter path by omitting the affix(es) as reading morphologically complex words needs longer process compared to roots and thus more time consuming (see sentence 1001 and 2801).

Among the deviations produced by the participants, there were eight products that were formed after experiencing more than one process. For this type of process, the term combination is used to refer to it. There were five types of combination processes that occurred in the deviations. Among the five types, affix omission-root substitution was the most frequently occurred (37.5\%), and followed by affix omission-affix substitution (25\%). Meanwhile, there was only one occurrence in each of the rest of the three types of combination: (a) affix omission - root substitution - affix substitution, (b) affix addition-affix substitution, and (c) affix substitution root substitution.

In the first type of combination (affix omission-root substitution) there was one occurrence found. In this type, target word experiences omission in its one or more affixes as well as the change in the root word. The following example illustrates the occurrence.

2001 (Target) sekawanan zebra berlarian di rerumputan menghindari singa [A zeal of zebras run on the grassland to avoid the lion]

(Participant 2) sekelas sebelah berlarian di rumputan menghindari singa. [A class of the other side run on the rumputan (meaningless) to avoid the lion]

In this occurrence, the target word sekawanan 'a zeal' changed into sekelas 'the whole class'. The omission that occurred in this word lied in the suffix -an. In addition, the root word kawan was read as kelas. Meanwhile, the prefix se-remained. This process produced a word other than the target word which was significantly different both in meaning and form.

There were several predictions that can be the possibilities on why and how the produced deviation turned out that way. Kintsch and Kintsch (2005) argued that the comprehension processes require the delicate interaction of several component processes that integrate information from the page that the readers are reading with their background knowledge and experience, subject to a multitude of contextual constraints. This implies that participants' background knowledge and experience also contribute to their reading comprehension performance (Rydlan, Aukrust, and Fullan, 2012). In other words, the first possibility related to their background knowledge of the semantic meaning of the words that were included in the sentence. Since morpheme is highly related with semantic meaning, the deviation in morphemic level might create a strange mental image during the participants' reading process. In this case, when Participant 2 failed in reading the suffix - an when he read the word sekawanan, the word sekawan might appear in his mental image. However, his background knowledge about animal, which in this case is zebra, might perceive this to be a strange behaviour of animal to be 
emotionally close in terms of friendship just as how the word sekawan means semantically. Therefore, he rejected this idea and turned sekawan into sekelas which could not be accepted as common knowledge that animals are very unlikely to attend school. However, since the time was limited and short, the last word, sekelas, was chosen.

The second possibility was related to their reading model: sublexical approach or whole word approach. Readers who apply sublexical approach depend on their spelling ability. Young Indonesian readers are usually taught to read using this method because of the orthographical transparency of the Indonesian language. However, expert readers use whole word approach because as they gain reading experience; they develop a collection of sight word (Anjarningsih, 2019). Sight words are the words that are read very frequently so the relationship of the visual form and the sound have been carved in the readers' mind. Therefore, expert readers, particularly teenage and adult readers, do not have to spell anymore as they have been familiar with the form. This process might be the reason why Participant 2 only read the beginning of the words correctly. The first three letters of the word sekawan and sekelas were similar and pronounced the same. In line with Helenius et al.'s (1999) evidence, Participant 2 could only read the beginning of the words correctly. In addition, the dual-route theory of reading aloud and the dual-route theory of reading comprehension are logically independent (Coltheart, 2005). In other words, the correctness of one says nothing about the correctness of the other. This might explain why Participant 2 produced a meaningful yet semantically unrelated word, in terms of the context of the sentence. However, since the sequence of the morphological processes that occurred in the participants' mind (e.g., whether the omission or the root change occurred first) and the Participants' reading model were still beyond the limitation of this study, further research was needed to make claim on how and why the produced words turned out to be very different.

A similar process also occurred in the second product that belongs to this category: sebagian 'a part of'. The following transcription illustrates the occurrence in textual domain.

2901 (Target) Arif mengerjakan sebagian tugasnya semalam. [Arif does (a part) of his assignment last night]

(Participant 1) Arif mengerjakan sebagai tugasnya semalam. [Arif does (as) of his assignment last night]

(Participant 2) Arif mengerjakan sebagai tugasnya semalam. [Arif does (as) of his assignment last night]

In this case, Participant 1 and 2 omitted the suffix - an, so they read the original root word, bagi 'divide', as bagai 'as if'. Similar to the previous deviation, this changed the meaning.

The second type of combination process is affix omission and affix substitution. This means that there were one or more affix in the target word that are omitted and the other changed into another affix. Both participants produced a similar deviation for this target word. The illustration of this can be seen in the following.

901 (Target) Azra mendapat juara kelas jadi Ayah menghadiahinva mainan baru. [Azra becomes the class champion so Father reward him a new toy]

(Participant 1) Azra mendapat juara kelas jadi Ayah menghadiahkan mainan baru. [Azra becomes the class champion so Father reward a new toy] 
(Participant 2) Azra mendapat juara kelas jadi Ayah menghadiahkan mainan baru. [Azra becomes the class champion so Father reward a new toy]

The target word menghadiahinya 'giving someone a present' is a complex word that consists of three affixes (one prefix and two suffixes) and a root word. The target word was designed to be quite difficult phonologically and morphologically. This consists of a vowel sequence which can be quite confusing to read and other similar sound in each of the segment. In addition, this target word has six syllables that consists of three syllables for three affixes and three syllables root word. Apparently the two participants tackled this difficulty by omitting one of the suffix, $-i$, and thus shortened the word. Then they changed the last suffix -nya into -kan. Moreover, the affixes meng- $i$ indicated that the sentence required a direct object to make the sentence accepted appropriately. In this case, the direct object, the person who gets the reward, is represented by affix -nya. In this occurrence, by omitting the affix - nya, the participant omitted the direct object that is required for affix meng-i. Both of the participants substituted affix $-i$ with -kan and the noun phrase mainan baru 'new toy' becomes the direct object. This occurrence demonstrated that even though the deviation causes no change in the whole meaning of the sentence, there is a slight change in the essence of the sentence.

The last combination process which included omission occurred in the target word kerajaan 'kingdom'. The following example shows the deviation that occurred.

2201 (Target) Permaisuri bekerja keras membuat kerajaannya menjadi makmur. [The empress works hard to make her kingdom prosperous]

(Participant 1) Permaisuri bekerja keras membuat kerjanya menjadi makmur. [The empress works hard to make (her work) prosperous]

From the text, it can be seen that Participant 1 applied several processes in his attempt to read the target word. The participant omitted one of the suffix, omitted one letter which then changed the meaning of the root word, and changed the prefix into the part of product root word. Originally, the target word consists of five syllables. The word consists of three affixes: one prefix (ke-) and two suffixes (-an, -nya), and one root word that consist of two syllables ra-ja 'king'. However, during the reading task, Participant 1 omitted the suffix -an. After that, he either omitted one letter $a$ in the second syllable, kept the prefix and changed it into part of the new root word, or he simply omitted the prefix ke- and changed the original root word raja 'king' into kerja 'work'. Either way, the process created a different word.

The last type of combination involves affix addition and affix substitution process. This means that there were one or more affixes added while one or more original affixes changed. This process occurred in the word berjalan 'walk'. The following transcription illustrates the text in which the deviation occurred.

401 (Target) setiap hari adikku pulang berjalan dari sekolah sampai ke rumah. [Every day my younger sibling goes home by (walking) from school until home]

(Partisipant 2) setiap hari adikku pulang perjalanan dari sekolah sampai ke rumah. [Every day my younger sibling goes home by (trip) from school until home] 
Unlike most deviations which involved at least an omission, Participant 2 added the suffix - an when he read the target word. He then read the prefix ber- as per-. The way Participant 2 read $[\mathrm{b}]$ as $[\mathrm{p}]$ and vice versa implied that there was a possibility that this affix substitution happened due to 'mirror effect' that typical dyslexic readers experienced whenever they the letters looked alike. Hence, perjalanan might appear as berjalan in their mental representation. Based on the activation-verifcation model suggested by Paap et al. (1982), during the word recognition, semantic effect is also taken into account. Thus, if there is a semantic context, words will be verified semantically. Then, the words that were semantically related to the candidate were set in their mental lexicon and were verified first. This implied that, based on this model, once the participant read it as perjalan, somehow it was hardly accepted since there was no word such as perjalan in Indonesian. Therefore, to make the word make sense, he unconsciously added suffix $-a n$ to make it more acceptable. This process changed the target word which was a verb into a noun, perjalanan 'trip'. Unlike the cases in omission types, in this occurrence, the participant might initiate a verification process during the word recognition process as the word in their mental representation was unacceptable in Indonesian.

The next type of morphological process occurred in the deviations is root changing. During the process, there was no changing in the affix(es) of the target word. Instead, it was the root word that changed. The following transcription illustrated the occurrence of this deviation.

3601 (Target) Orang-orang mengagumi kepandaian Kartini yang melebihi perempuan di zamannya. [The people adore Kartini's intelligence which outperforms the women in her era]

(Participant 2) Orang-orang mengampuni kepandaian Kartini yang melebihi perempuan di samannya. [The people forgive Kartini's intelligence which outperforms the women in her era]

In reading this target word, Participant 2 did not change the prefix meng- and suffix $-i$ in the target word. Instead, he changed the root word kagum 'adore' into ampun 'forgive'. Therefore, this deviation produced new word mengampuni 'to forgive'.

The next word to experience this process is berawan 'cloudy'. Similar to the previous deviation, Participant 2 left the prefix unchanged. He only changed the root word awan 'cloud' into warna 'colour' which has a different meaning than the root of the target word. The following transcription illustrated the text in which the deviation occurred.

1201 (Target) Sore itu, ketika langit mulai berawan, Ayah bergegas pulang. [That afternoon, when the sky starts to be cloudy, Father hurries home]

(Participant 2) Sore itu, kecil langit mulai berwarna Ayah bergegas pulang. [That afternoon, when the sky starts to be colorful, Father hurries home]

There were three similarities that were found in these occurrences. The first similarity was that the process did not change the word class of the deviation. Both target words and the deviations were in the same word class. In the first occurrence, which target was a verb (mengagumi), the product was also a verb (mengampuni). The same was also applied in the second occurrence, which target word was an adjective (berawan), the product was also an adjective (berwarna). The second similarity lied in the number of syllables. Both the target words and their 
deviation counterparts had a similar number of syllables. In the first and second occurrence, they both consist of four and three syllables respectively.

The next process found in the deviation was suppletion. In this process both participants simply read the target words into completely different words. There were two target words that experienced this process. Among the words listed, most of the target words that experienced this process were nouns. The following are the texts in which the deviation occurred.

3801 (Target) Setelah para pahlawan berjuang di perang yang menakutkan, akhirnya negeri ini merdeka. [After the heroes fight in terrifying battle, finally this country becomes independent]

(Participant 2) Setelah para perawan berjuang di perang yang menakutkan, ahirnya negeri ini meredeka. [After the virgins fight in terrifying battle, finally this country becomes independent]

2001 (Target) sekawanan zebra berlarian di rerumputan menghindari singa. [A zeal of zebras run on the grass land to avoid the lion]

(Participant 2) sekelas sebelah berlarian di rumputan menghindari singa. [A class of the other side run on the rumputan (meaningless) to avoid the lion]

In the monomorphemic words, the morphological deviation happened twice. Both of them can be categorized into the type of suppletion. Examples are the word pahlawan 'hero', which becomes perawan 'virgin', and Zebra 'an animal' which becomes sebelah 'beside'. The two produced words were meaningful. More interestingly, the target root in the first word consists of three syllables (pah-la-wan) and two syllables in the second word (Ze-bra). In the produced words, perawan as the deviation of pahlawan also consists of three syllables, that is, pe-ra-wan, and the word sebelah as the deviation of Zebra also consists of three syllables, that is, se-be-lah. It seems that the morphological deviation in the monomorphemic words tends to occur on monomorphemic words with more than one syllable resulting in monomorphemic words with at least similar number of syllables or more additional number of syllables.

Law, Wouters, \& Ghesquière (2015) suggested that adults with dyslexia made a shift in the underlying cognitive mechanism of word reading. Their research demonstrated that by regression analysis, the dyslexic readers involved in their study exhibited a shift away from an association between phonological skills and word reading to a greater involvement of morphological awareness. As Burani, et al. (2008) also proposed, the findings in this research implied that in compensating their lacking phonological awareness, which was necessary in a reading process, they relied more on their morphological awareness. Since the nature of written morphemes allows segmentation of morphologically complex words into their constituents (Taft, 2003), readers might comprehend the word by drawing the meaning of the words through the morphemes (roots and suffixes). Thus, this enables an alternate path of sublexical processing that ultimately facilitates word reading by minimizing dependency on phonological processing. However, reading morphologically complex words needs a longer process compared to reading root words. Since it is more time consuming, dyslexic readers might choose a shorter path by omitting the affix(es) as shown in this study.

Often times, in the words with inflectional affixes, the produced deviations were found in the form of roots. With some limitation compared to normal readers, this might happen due to the 
morphological knowledge that was acquired by the participants along with their experience in reading activities. Cavalli, et al. (2017) suggested that in a language where orthography is encoded systematically by its morphology, the words may act as a functional reading unit that facilitates the rapid decoding of written words to word meaning because the frequently appearing morphemes are systematically associated with meaning. Thus, by acquiring this in dyslexic readers' respective language, including participants in this study, encountering with reading material in such a long period may give them some benefit from the repeated presentation of morphemes. This may lead them to develop strong connections between orthographic representation, word identification, and access to the meaning.

The last process found was syllable addition. In this process, there was a syllable added in one of the morphemes. This deviation occurred in the following text.

701 (Target) Ketika aku ke pantai bersama seluruh keluargaku, cuacanya sangat panas. [When I go to the beach with the entire of my family, the weather is so hot]

(Participant 2) Ketika aku ke pantai bersama seluruh keluarga aku, cuaca sangat panas. [When I go to the beach with the entire of my family, the weather is so hot]

Participant 2 added one syllable - $a$ - between free morpheme keluarga 'family' and bound morpheme - $k u$ 'my'. It results in the construction that consists of two words. The first word was the root and the second word consisted of two syllables. In other words, he separated the free morpheme with its bound morpheme and formed compound words. However, since the bound morpheme involved in this occurrence was inflectional suffix, none of the meaning of the morphemes in the target word was changed. The formed compound words shared similar meaning with the target.

The findings in this research were consistent with Elbro and Arnbak's (1996), in that dyslexic adolescents were benefitted significantly more from reading a text segmented into morphemes than into syllable. This also suggests that adolescent dyslexic readers rely more on morphemes to compensate their lack of phonological awareness. Thus, instead of reading the words phonetically by their syllables, they read it based on the morphemes and drew the meaning from morphemes. In relation to this study, the data also implied that most of the deviations formed more words with different meanings than non-words. In other words, the morphological processes occurred in the deviation produced individual meaningful words much more than the meaningless ones. Since they relied more on morphemes, which also represent their own meaning, whatever types of morphological process that the participants chose, the produced words would be meaningful as discrete units.

\section{CONCLUSION}

As formulated in the research question, the goal of this study was to find the patterns of the morphological deviations produced by two dyslexic adolescents. The data showed that $98 \%$ of the deviations were found in polymorphemic words. This happened as the more morphologically complex the words, the more limited morphological process performed by the dyslexic readers as it involved more numbers of smaller linguistic units to be processed. Also, the participants tended to make the words somewhat simpler by omitting the affix and reading only the root words. The data showed that $58 \%$ of the deviations were in the form of omission. Therefore, affix omission 
became the most frequent process that occurred. In addition, the morphological deviations produced more meaningful words than non-words (92\%). However, the produced words are only meaningful in discrete units. This occurred as the produced words result in different meanings in comparison to the words written in the target text.

\section{Note}

We would like to thank two anonymous reviewers for their very helpful comments on the earlier draft of the paper.

\section{REFERENCES}

Alwi, H., Dardjowidjojo, S., Lapoliwa, H., Moeliono, A.M. (1998). Tata bahasa baku bahasa Indonesia (Third Edition). Jakarta: Balai Pustaka.

American Psychiatric Association. (2013). DSM 5. American Psychiatric Association.

Anjarningsih, H. Y. (2011). Jangan kucilkan aku karena aku tidak mahir membaca: Pentingnya identifikasi dini disleksia untuk masa depan anak. Yogyakarta: Pustaka Cendekia Press.

Anjarningsih, H. Y. (2019). Disleksia - Perkembangan di Indonesia. Jakarta: Yayasan Pustaka Obor Indonesia.

Beaton, A. A. (2004). Dyslexia, reading, and the brain. New York: Psychology Press.

Bellocchi, S., Muneaux, M., Bastien-Toniazzo, M., \& Ducrot, S. (2013). I can read it in your eyes: What eye movements tell us about visuo-attentional processes in developmental dyslexia. Research in Developmental Disabilities, 34(1), 452-460.

Bosse, M. L., \& Valdois, S. (2003). Patterns of developmental dyslexia according to a multi-trace memory model of reading. Current Psychology Letters. Behaviour, brain \& cognition, $1(10)$.

Burani, C., Marcolini, S., De Luca, M., \& Zoccolotti, P. (2008). Morpheme-based reading aloud: Evidence from dyslexic and skilled Italian readers. Cognition, 108(1), 243-262.

Burani, C. (2009). Reading fluency and morpho-lexical processing: Developmental studies in Italian. Revista de Logopedia Foniatría Y Audiología, 29(2), 97-103.

Casalis, S., Colé P., \& Sopo, D. (2004). Morphological awareness in developmental dyslexia. Annals of Dyslexia, 54(1), 114-138.

Carlisle, J., \& J, F. (2003). Lexical processing of morphologically complex words in the elementary years. Scientific Studies of Reading, 7(3), 239-253.

Cavalli, E., Duncan, L. G., Elbro, C., El Ahmadi, A., \& Colé, P. (2017). Phonemic-Morphemic dissociation in university students with dyslexia: An index of reading compensation? Annals of Dyslexia, 67(1), 63-84.

Chik, P. P., \& Ho, C. S. (2012). Contribution of discourse and morphosyntax skills to reading comprehension in Chinese dyslexic and typically developing children. Annals of Dyslexia, $62(1), 1-18$.

Chung, K. K., Ho, C. S. H., Chan, D. W., Tsang, S. M., \& Lee, S. H. (2010). Cognitive profiles of Chinese adolescents with dyslexia. Dyslexia, 16(1), 2-23. 
Coltheart, M. (2005). Modeling reading: The dual-route approach. In M.J. Snowling, \& C. Hulme (Eds.), The science in reading: A handbook (pp. 6-23). Oxford: Blackwell Publishing.

Deacon, S. H., Parrila, R., \& Kirby, J. R. (2006). Processing of derived forms in highfunctioning dyslexics. Annals of Dyslexia, 56(1), 103-128.

De Groot, A. (2013). Reading. in F. Grosjean, \& P. Li, The Psycholinguistics of Bilingualism. Sussex: Wiley-Blackwell, pp 73-99.

Elbro, C., \& Arnbak, E. (1996). The role of morpheme recognition and morphological awareness in dyslexia. Annals of dyslexia, 46(1), 209-240.

Field, J. (2003). Psycholinguistics: A Resource Book for Students. London: Routledge.

Freyd, P. \& Baron, J. (1982). Individual differences in acquisition of derivational morphology. Journal of Verbal Learning and Verbal Behavior, 21(3), 282-295.

Goodwin, A. P., Gilbert, J. K., \& Cho, S. J. (2013). Morphological contributions to adolescent word reading: An item response approach. Reading Research Quarterly, 48(1), 39-60.

Helenius, P., Salmelin, R., Service, E., \& Connolly, J. F. (1999). Semantic Cortical Activation in Dyslexic Readers. Journal of Cognitive Neuroscience, 11(5), 535-550.

Kałdonek-Crnjaković, A. (2015). Age effect on spelling development in dyslexic Croatian English as a Foreign Language (EFL) learners. Govor, 32 (2), 99-129. Retrieved from https://hrcak.srce.hr/165983

Katamba, F. (2005). English Words. New York: Routledge.

Kieffer, M. J. (2014). Morphological awareness and reading difficulties in adolescent Spanishspeaking language minority learners and their classmates. Journal of Learning Disabilities, 47(1), 44-53.

Kintsch, W. \& Kintsch, E. 2005. Comprehension. In Scott. G. Paris, \& S. A. Stahl (Eds.), Children's Reading Comprehension and Assessment, 71-92. Mahwah: Lawrence Erlbaum Associates, Inc.

Koda, K. (2005). Insights into second language reading: A cross-linguistic approach. The Cambridge Applied Linguistics Series. Cambridge, UK: Cambridge University Press.

Kridalaksana, H. (1998). Introduction to word formation and word classes in Indonesian. Fakultas Sastra, Universitas Indonesia.

Lallier, M., Valdois, S., Sangosse-Lassus, D., Prado, C., \& Kandel, S. (2014). Impact of orthographic transparency on typical and atypical reading development: Evidence in French-Spanish bilingual children. Research in Developmental Disabilities, 35(5), 11771190.

Law, J. M., Wouters, J., \& Ghesquière, P. (2015). Morphological awareness and its role in compensation in adults with dyslexia. Dyslexia, 21(3), 254-272.

Law, J. M., Veispak, A., Vanderauwera, J., \& Ghesquière, P. (2017). Morphological awareness and visual processing of derivational morphology in high-functioning adults with dyslexia: An avenue to compensation? Applied Psycholinguistics.

Lieber, R. (2009). Introducing morphology. Cambridge: Cambridge University Press. 
McNamara, D. S., \& Kendeou, P. (2011). Translating advances in reading comprehension research to educational practice. International Electronic Journal of Elementary Education, $4(1), 33$.

Muroya, N., Inoue, T., Hosokawa, M., Georgiou, G. K., Maekawa, H., \& Parrila, R. (2017). The role of morphological awareness in word reading skills in Japanese: A within-language cross-orthographic perspective. Scientific Studies of Reading, 21(6), 449-462.

Nagy, W. E., Carlisle, J. F., \& Goodwin, A. P. (2014). Morphological knowledge and literacy acquisition. Journal of Learning Disabilities, 47(1), 3-12.

Paap, K. R., Newsome, S. L., McDonald, J. E., \& Schvaneveldt, R. W. (1982). An activationverification model for letter and word recognition: The word-superiority effect. Psychological Review, 89(5), 573.

Pacheco, M. B., \& Goodwin, A. P. (2013). Putting two and two together. Journal of Adolescent \& Adult Literacy, 56181(7), 541-553.

Patel, DR., Omar, HA., Greydanus, DE., Merrick, J. (2011). Neurodevelopmental disabilities: Clinical care for children and Young Adults. New York: Springer

Rydland, V., Aukrust, VG., \& Fulland, H. 2012. How word decoding, vocabulary and prior topic knowledge predict reading comprehension. A study of language-minority students in Norwegian fifth grade classrooms. Reading and Writing 25(2). 465-482.

Siegel, L. S. (2008). Morphological awareness skills of English language learners and children with dyslexia. Topics in Language Disorders, 28(1), 15-27.

Papodopoulos, T., Parrila, R. K., \& Kirby, J. R. (Eds.). (2014). Cognition, intelligence, and achievement: A Tribute to JP Das. Elsevier.

Sprenger-Charolles, L., Siegel, L. S., \& Bonnet, P. (1998). Reading and spelling acquisition in French: The role of phonological mediation and orthographic factors. Journal of Experimental Child Psychology, 68(2), 134-165.

Sprenger-Charolles, L., \& Colé, P. (2003). Lecture et Dyslexie. In Berthiaume, R., \& Daigle, D. (2014). Are dyslexic children sensitive to the morphological structure of words when they read? The case of dyslexic readers of French (pp 253). Dyslexia, 20(3), 241-260.

Sprenger-Charolles, L., Siegel, L. S., Jiménez, J. E., \& Ziegler, J. (2011). Prevalence and reliability of phonological, surface, and mixed profiles in dyslexia: A review of studies conducted in languages varying in orthographic depth. Scientific Studies of Reading, 15(6), 498-521.

Snowling, M. J., \& Stockhouse, J. (2006). Dyslexia, speech, and language: A practitioner's handbook. Sussex: Whurr Publishers Limited.

Taft, M. (2003). Morphological representation as a correlation between form and meaning. In E. Assink, \& D. Sandra (Eds.), Reading complex words (pp. 113-137). Amsterdam, NL: Kluwer.

Tong, X., Deacon, S. H., Kirby, J. R., Cain, K., \& Parrila, R. (2011). Morphological awareness: A key to understanding poor reading comprehension in English. Journal of Educational Psychology, 103(3), 523. 
Undheim, A. M. (2009). A thirteen-year follow-up study of young Norwegian adults with dyslexia in childhood: reading development and educational levels. Dyslexia, 15(4), 291.

Zhang, J., Lin, T. -J., Wei, J., \& Anderson, R. (2014). Morphological awareness and learning to read Chinese and English. In X. Chen, Q. Wang, \& Y. Luo (Eds.), Reading Development and Difficulties in Monolingual and Bilingual Chinese Children (pp. 3-22). Dordrecht: Springer.

Ziegler, J. C., \& Goswami, U. (2005). Reading acquisition, developmental dyslexia, and skilled reading across languages: A psycholinguistic grain size theory. Psychological Bulletin, 131(1), 3-29. 